\title{
Review Article \\ Commercialization of Sago through Estate Plantation Scheme in Sarawak: The Way Forward
}

\author{
Hafizan Mohamad Naim, ${ }^{1}$ Ahmad Nizar Yaakub, ${ }^{1}$ and Dayang Asmah Awang Hamdan ${ }^{2}$ \\ ${ }^{1}$ Department of Politics and International Relations, Faculty of Social Sciences, Universiti Malaysia Sarawak, \\ 94300 Kota Samarahan, Sarawak, Malaysia \\ ${ }^{2}$ Department of Development Studies, Faculty of Social Sciences, Universiti Malaysia Sarawak, 94300 Kota Samarahan, \\ Sarawak, Malaysia \\ Correspondence should be addressed to Hafizan Mohamad Naim; hafizanmohamadnaim@gmail.com
}

Received 12 May 2016; Revised 29 August 2016; Accepted 7 September 2016

Academic Editor: Maria Serrano

Copyright (C) 2016 Hafizan Mohamad Naim et al. This is an open access article distributed under the Creative Commons Attribution License, which permits unrestricted use, distribution, and reproduction in any medium, provided the original work is properly cited.

\begin{abstract}
Sago has been hailed as a next viable commodity in Sarawak, Malaysia, given its potential as a versatile crop. Realising its potential, Sarawak state government has started initiatives to stimulate sago plantation from subsistence farming to estate plantation. The move of introducing sago estate plantation is a bold one considering that Malaysia is the first country introducing such plantation design. This is a reflection on sago estate plantation in the state of Sarawak. It is observed that, in order to ensure success of the plantation scheme, factors such as rigorous land consolidation programme aiming to maximize sago production; introduction of a modern planting method that integrates well with the traditional planting method; rigorous scientific research in finding the best sago variety that produces high yield; effective communication between related agencies and smallholders; and concentrated involvement of all actors, governmental agencies, mills, and smallholders, have to be addressed accordingly. To conclude, it is hoped that this writing can be utilized as part of a contribution to accelerating commercialization of sago as a next viable commodity crop not only in Sarawak but in Southeast Asia as a whole.
\end{abstract}

\section{Introduction}

Sago (Metroxylon sagu) is a palm species which is indigenous to Southeast Asia region, specifically Malaysia, Indonesia, Papua New Guinea, and the Philippines. It is known for its tolerance to wet growing condition and has a main advantage of the ability to thrive in harsh swampy peat environment [1]. Besides that, sago palm is resistant to extreme weather changes making it a versatile plant as it takes less maintenance to cultivate. In regard to the replanting process, sago palm needs minimum care and replanting is not necessary as the parent palm proliferates suckers. Comparing sago palm with other crops such as palm oil, the latter requires replanting every 25 years which is quite costly making sago palm a better option for planting.

In regard to sago production, currently Malaysia is the third largest sago producer in the world after Indonesia and Papua New Guinea which combined produce approximately 94.6 percent [2] of the world production. Indonesia, the biggest producer of sago starch in the world, produces 585,093 tons per year [3].

In terms of hectarage, the latest data produced in 2014 estimates that Indonesia has the world's largest hectarage of sago plants (Table 1). Comparing the data with data produced by the Department of Agriculture Sarawak, by 2012, all four districts in Mukah division, namely, Mukah, Dalat, Matu, and Daro, have cultivated an estimated 11,112 hectares, 28,169 hectares, 4,306 hectares, and 3,149 hectares of sago, respectively. Out of 67,957 hectares of land cultivated with sago in Sarawak, 43,426 hectares was planted by small-scale sago farmers and 24,531 hectares was planted by commercial sago plantation. Sago is deemed as a next viable commodity crop in Sarawak given the fact that about 1.69 million hectares of peat soil can be cultivated with this palm [4].

Realising sago potential, Sarawak government has started initiatives to stimulate sago plantation from subsistence farming to estate plantation. One of the initiatives is by appointing Land Custody and Development Authority (LCDA) to 
TABLE 1: Estimated sago hectarage by countries.

\begin{tabular}{lc}
\hline Country & Estimated sago (ha) \\
\hline Indonesia & $2,942,278$ \\
Papua New Guinea & $1,020,000$ \\
Malaysia & 59,000 \\
Thailand & 5,000 \\
Philippines & 3,000 \\
Other countries & 3,000 \\
Total & $4,032,278$ \\
\hline
\end{tabular}

Source: Farmer Empowerment to Increase Productivity of Sago Farming [3].

facilitate the process of consolidating land for estate sago plantation. This is a bold move given that sago plantation in Southeast Asia is mainly planted as smallholder crop. Even Indonesia and Papua New Guinea as the largest sago producers in the world have yet to formulate a practical plantation system which may transform smallholder sago plantation into estate plantation.

\section{Change from Sago as Staples to Income Generating Source}

Historically, sago palm plays an important role as a staple food source for Sarawak coastal Melanau communities. Looking at a larger picture, sago can be described as a native crop in Southeast Asia that has deep historical, cultural, and socioeconomic rooting in the communities' lives. It plays an important role in supporting cultural activities, staple food source, and materials for houses and bridges as well as maintaining water conservation [5]. However, in the case of Sarawak coastal Melanau in the area of Mukah, the role of sago as a staple food has slowly been replaced by rice. It is observed that the choice of consuming rice which is difficult to grow compared to sago which is very abundant is a sociological choice rather than an economical one. The same observation has been observed by researchers in Indonesia and Papua New Guinea which postulates that rice is attributed as a status symbol in the community which is viewed as a shameful alternative if people are forced to eat it $[5,6]$. For the coastal Melanau in Sarawak, the decline of sago consumption does not contribute to the decline of sago farming; rather, sago's role changes from being a source of food to a source of income. Farmers, rather than using sago as their staple food, sell sago boles to sago mills in exchange for money as a source of income which in turn enables them to buy staples such as rice, food, and goods.

In regard to sago as a source of income generation, sago industry is known to possess a great potential as utilization of sago starch is very versatile. The identified potential utilization aspects of sago starch are many, ranging from traditional uses, uses in food industries, uses in nonfood industries, and uses in biotechnology to usage for other industries such as biomass and poultry industry [7]. Besides, the advantages of utilizing sago starch for food products and nonfood products are as follows (Table 2) [8].
There are three main components that play an important role in the Sarawak sago industry: (a) sago factories that play an important role as a buyer where sago farmers can sell their sago boles; (b) local market which has an everlasting demand towards traditionally processed sago starch; and (c) local traditional sago starch-based food industry which has an increasing demand towards sago starch. All three components act as a provider for sago farmers where they can sell their sago boles and sago starch.

To discern the difference between sago farming in Sarawak and sago farming in other areas outside Malaysia, Sarawak sago farming is a mix of both planted and natural stands while sago farming in Indonesia and Papua New Guinea is mostly from wild trees. The only drawback for Sarawak sago industry is that more than half of the sago cultivation area in Sarawak is dominated by small-scale sago farmers. Often, the areas are scattered making it difficult for consolidation and rehabilitation process.

\section{Maximizing Sago Production through Land Consolidation Programme}

It is a common belief that large-scale agricultural ventures are needed in order to achieve high yields and higher production volume. Under this belief, sago has received a rejuvenating approach where large-scale sago cultivation has been introduced in 1980, developed by Estate LCDA [9]. The idea is that Sarawak tries to be the pioneer of large-scale sago plantation given its potentials as a viable future cash crop besides rubber and oil palm plantations. One of the reasons for the move to diversify Sarawak agriculture sector may be attributed to the 1980s fluctuations of primary products in the world market especially rubber. Besides that, sago is deemed a potential future cash crop because of its remarkable characteristics as a sustainable crop. According to Stanton [10], sago holds its own potential because of its massive advantages compared to other crops; the advantages of sago include (a) being economically acceptable, (b) being relatively sustainable, (c) being environmentally friendly, (d) being uniquely versatile, (e) being vigorous, and (f) promoting socially stable agroforestry system.

Attempts have been made by both Malaysia and Indonesia in order to transform sago forest to commercial sago plantation. Both Malaysia and Indonesia face different contextual challenge in regard to commercializing their sago plantation industry, Indonesia in its technological aspect and Malaysia in available land area aspect. Indonesia is well known to be the most potential producer of sago starch in the world because it holds the largest hectarage of sago palm in the world, accounting for 51.3 percent [2], while Malaysia (Sarawak in particular) holds its own edge as Sarawak manages to become the largest world exporter due to its sago flour processing technology despite having only estimated sago planting area of above 60,000 hectares.

Relating to Malaysia, in order to ensure successful transformation from natural stands and small-scale sago plantation to estate sago plantation, this process involves structural modernization in the process of planting and rehabilitation 
TABLE 2

\begin{tabular}{ll}
\hline $\begin{array}{l}\text { Utilization of sago } \\
\text { starch }\end{array}$ & Advantages \\
\hline & $\begin{array}{l}\text { (i) Encapsulation of flavour or aroma } \\
\text { (ii) Yellow noodles with reduced gluten content and prolonged shelf life } \\
\text { (iii) Better gelling characteristics, more clarity, and better aroma in sauces and jams } \\
\text { Food products }\end{array}$ \\
& $\begin{array}{l}\text { (iv) Improved texture in fritters } \\
\text { (v) Prolonged crispiness when served } \\
\text { (vi) Modified sago starch for thickening agents in soups, sauces and fruit fillings, emulsifiers in instant batter mixes } \\
\text { and beverages, and stabilizers in freeze-thaw products such as frozen and canned foods }\end{array}$ \\
& $\begin{array}{l}\text { Sago starch can be modified for the following: } \\
\text { (i) Coating agent in biodegradable film }\end{array}$ \\
(ii) Thickener in adhesive preparation and printing \\
(iii) Sizing agents in papermaking \\
(iv) Dusting powder in cosmetic and hypoallergenic powder
\end{tabular}

process. Most of the world's supply of sago starch is harvested from wild trees; therefore, attempts to harvest the crop from natural stands need massive areas planted specifically with sago plantation. In regard to Sarawak, sago farms in Sarawak are mostly operated by small-scale sago farmers. Therefore, the move to create large-scale plantation will compel consolidation of small-scale farms and unused arable land. To further develop Sarawak sago industry, Sarawak government has also implemented land consolidation programme which involved smallholders through Sago Smallholder Satellite Estate Development Programme (SSSED) managed by LCDA. SSSED is an effort made by the state government to encourage the development of the sago industry by establishing estate-like sago plantation. Currently, SSSED project benefitted 4,875 smallholders with 2,883 hectares that has been successfully established under the project [11]. SSSED project concentrates on maximizing sago production through the introduction of efficient sago farming and farming design. Besides that, new modern methods are also introduced in the SSSED project to optimize sago production. This includes the introduction of the use of fertilizer and suckers pruning (which was previously nonexistent under the traditional approach).

\section{Finding the Best Sago Variety through Rigorous Scientific Research}

Another issue that needs to be addressed is the competitiveness of the crop from the perspective of return on investments given its long gestation period of about 10 to 15 years [4]. Comparing sago with oil palm, the gestation period for oil palm is only four years which is more than twice the gestation period of sago. The long maturity period of sago palm gives rise to concerns among small-scale farmers in the aspect of their daily living sustenance. Even though it has been promoted that smallholders may plant perennial crops such as bananas and pineapples alongside growing sago plant, most of the land is swampy, acidic peat soils and is often subject to flooding, making it difficult to plant sustaining crops. Some also argue that sago is still far lagging behind in terms of financial profitability compared to oil palm, discouraging investors and smallholders from commercializing sago plantation. However, comparing sago palm with oil palm, the latter requires replanting every 25 years which is quite costly making sago palm a better option for planting as sago does not require replanting.

As such, it is imperative that the effort of improving the quality of sago planting materials is aiming specifically to reduce the average gestational period of 10 to 15 years to lower than 10 years and to improve the quality of starch produced per sago bole. Thus, a specific body has been established in 1993 by the Sarawak state government under the name of Crop Research and Application Unit (CRAUN). It is a research body that specializes in researching these aspects through plant selection and breeding. Most of the results highlighted through the studies done indicate sago potential as a future crop but the only challenge that they are facing is the race of time. Due to the long gestation period, breeding work and research on sago clones take time to yield results. This is a difficult aspect of the transformation process of sago commercialization. Sago not only experiences hurdles in its move towards transforming the sector but also is experiencing direct competitiveness from other starch producing crops and existing cash crops primarily oil palm.

\section{Integration of Modern Planting Method with Traditional Planting Method}

In terms of technology advancement in regard to the sector, Malaysia spearheaded the application of modern agricultural technology in managing its large-scale sago plantation. However, in regard to the farming practice among smallholders, they still employ semitraditional and traditional methods. Looking at this as an area where it can be further enhanced for the advancement of the industry, the government is adamant to improve the farming method which is aimed at introducing efficiency. With respect to this, Sarawak government had developed strategies to facilitate efficient cultivation of sago palm by introducing proper drainage system and improved modern plantation methods. Differing 
from smallholders' practices, under SSSED, the plantation process and cultivation process have been designed to better suit the estate-like plantation process. Experimentation on mechanizing plantation farming has been done in Malaysia [12] complementing the SSSED large-scale plantation.

Modern method also introduces more agronomic practices with respect to crop establishment and maintenance. For example, under the modern method, the integration system is encouraged to optimize land use, suppress weeds, and provide income before sago can be harvested. Besides that, fertilizer application is introduced for sago planted in shallow and deep peat while in the traditional method fertilizer is not needed. Cluster maintenance is also introduced as well as sucker pruning in order to encourage natural growth and the establishment of suckers.

To further elaborate on the aspect of modern sago plantation methods, the large-scale plantation method has integrated both modern and traditional methods in its farming process. Modernization has been done in the planting phase whereby, prior to planting, land has to be cleared from vegetation especially dicotyledonous trees which may impede the growth of the suckers. Compared to the traditional method, only small clearings are sufficient in order for the suckers to be successfully planted. A systematic drainage system has also been formulated under the modern method whereby the depth of the drainage depends on the soil type (deep peat, shallow peat, or mineral soil). In comparison to the traditional method, drainage is constructed as long as the water level is sufficient for the whole farm. With respect to the suckers planting process, the modern method's systematic spacing design consists of a grid of points (7 meters $\times 7$ meters $\times 12$ meters) whereby the traditional method has a grid of points of 5 meters $\times 10$ meters, though farmers sometimes plant suckers unsystematically. Besides that, nursery technology has also experienced modernization through the development of clonal sago planting material and systematic sago sucker selection and sucker extraction process. Furthermore, employment of either raft nursery or polybag nursery method during the sucker nursing process has made large-scale planting possible.

Despite the leap forward in technological advancement on planting and cultivating sago, smallholders are reluctant to accept modern planting methods because they do not go well with their traditional planting method. Differing views from both communities and agencies with respect to the planting and cultivation process can cause contention which can hamper the transformation process if it is not being addressed accordingly. It is viewed that there is not enough communication done with respect to disseminating information on the benefits of integrating modern methods in the sago planting and cultivation process. SSSED project, for example, has met opposition from communities during the commencement of the project due to the communities' distrust of the methods employed during the planting process. It is shared widely among smallholders that some of the modern methods used are expected to be the reasons why some of the sago palms do not flourish as expected.

\section{Bridging Effective Communication between Related Actors}

Relating to the social issue of sago plant transformation process, the process itself involves not only the agencies such as governmental bodies, research agencies, and the industries but also the communities which, in this case, are smallholders sago farming communities. The consolidation and rehabilitation process and modern technological and research advancement would not yield a good result to the transformation process if there is misconception and miscommunication between the agencies and the communities. Relating to the issue of traditional and modern methods of planting and cultivating sago, it is imperative that a proper communication channel is established whereby information regarding the transformation process and methods used is transmitted successfully to the community. The communication which transpires from the interaction should not be expected to be a one-way communication but rather a twoway communication between all related actors.

\section{Fostering Involvement of All Actors Involved}

Transforming sago industry involves a collaborative effort of all actors involved. There are five actors identified involved in the industry which are the community (sago farmers and seasonal workers for sago felling), miller, entrepreneurs, governmental agencies, and research agencies. Every actor should be responsible for the advancement of the industry. Linking these actors to national natural resources development policies and institutions model by [13], a better understanding of the dynamics of the relationship can be highlighted (Figure 1).

Like in other crops, government intervention is needed in order to transform the sago industry. Unlike other crops, such as black pepper (Piper nigrum), rubber (Hevea brasiliensis), oil palm (Elaeis guineensis), cocoa (Theobroma cacao), tobacco (Nicotiana tabacum), and pineapple (Ananas comosus) which have their own governing board (Table 3), sago on the other hand does not have its own governing board.

Because of the nonexistence of sago board in Malaysia, sago mills play an important role as a driving force for the advancement of the industry as it controls the market price of sago bole in Sarawak. The dynamics between the price fixed by the mills and the boles produced by sago farmers can be observed through competitiveness of the price given by the mills which will determine the increase in the amount of sago boles produced by sago farmers.

\section{Future Perspective of Sago Estate Plantation}

Malaysia is the first country introducing sago estate plantation. The success of Sarawak state government endeavor in promoting cultivation of sago estate plantation is yet to be ascertained. Referring to [4], the difference between sago estate plantations with other perennial crops is that 


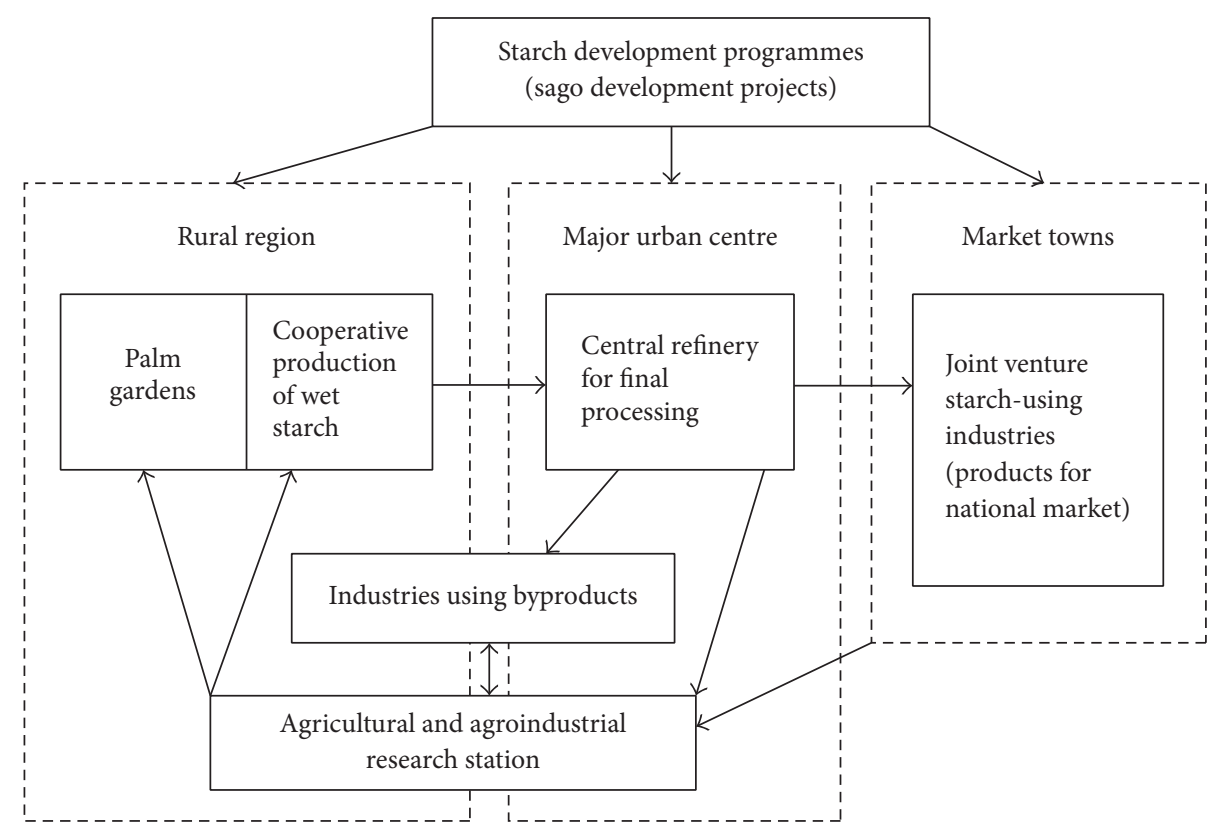

FIgURE 1: National natural resources development policies and institutions.

TABLE 3: Crops and governing board in Malaysia.

\begin{tabular}{lc}
\hline Crop & Governing board \\
\hline Black pepper & Malaysian Pepper Board (MPB) \\
Rubber & Malaysian Rubber Board (MRB) \\
Oil palm & Malaysian Palm Oil Board (MPOB) \\
Cocoa & Malaysian Cocoa Board (MCB) \\
Tobacco & National Kenaf and Tobacco Board (LKTN) \\
Pineapple & Malaysian Pineapple Industry Board (MPIB) \\
\hline
\end{tabular}

the latter is spearheaded by private entrepreneurs. Private entrepreneurs play an important role in ensuring the success of plantation venture. They act as one of the main elements in ensuring the advancement of clonal material and plantation technology for the formulation of a successful plantation scheme. Arguably, in the case of sago plantation, governmental and research agencies play an important role as a catalyst for the advancement of the plantation given the absence of private entrepreneurs in spearheading it. However, this does not mean that the role of the private entrepreneurs is not needed for the advancement of the industry. Expectantly, it is projected that the endeavor will be successful if a concerted effort has been given by all actors involved.

\section{Conclusion}

Sago has the potential to be an important commodity for Malaysia. Its role has changed from merely a staple food to an income generating source for the sago farmers and for export. Enormous effort has been made by the state government of Sarawak for land consolidation programme through LCDA and SSSED to spearhead the sago cultivation especially through estate plantation. Modern planting method is introduced which integrates well with the traditional method. CRAUN is entrusted with conducting rigorous scientific research in finding the best sago variety that produces high yield. Despite the focus on sago estate plantation, the Sarawak state government realised the importance of the smallholders to increase the sago production. As such, an effective communication between related agencies and the smallholders needs to be streamlined in order to avoid misconception and miscommunication has to be addressed accordingly. No doubt all this effort contributes to accelerating commercialization of sago as a next viable commodity crop for Sarawak and Southeast Asia.

\section{Abbreviations \\ LCDA: Land Custody and Development Authority \\ SSSED: Sago Smallholder Satellite Estate Development Programme \\ CRAUN: Crop Research and Application Unit.}

\section{Competing Interests}

The authors declare that there are no competing interests regarding the publication of this paper.

\section{Acknowledgments}

All authors currently receive a research grant under Kursi Tun Openg (Sago Chair), Universiti Malaysia Sarawak, for a research titled "Strategies for Sustainable Livelihood among Small-Scale Farmers in Mukah District of Sarawak." The authors also would like to thank CRAUN and Sungai Talau 
Research Station (STRS) for providing information needed for this research paper.

\section{References}

[1] K. R. Ruddle, "Sago in the new world," in Sago-76: Papers of the First International Sago Symposium, K. Tan, Ed., pp. 53-64, Kemajuan Kanji Sdn. Bhd, Kuala Lumpur, Malaysia, 1977.

[2] P. Istalaksana, Y. Gandhi, P. Hadi, A. Rochani, K. Mbaubedari, and S. Bachri, "Conversion of natural sago forest into a sustainable sago palm plantation at Masirei District, Waropen, Papua, Indonesia: feasibility study," in Proceedings of the 8th International Sago Symposium, Y. O. Karafir, F. S. Jong, and E. Fere, Eds., pp. 65-77, Universitas Negeri Papua Press, Manokwari, Indonesia, 2005.

[3] M. Ahmad, "Farmer empowerment to increase productivity of sago (Metroxylon sago spp) farming," International Journal on Advanced Science, Engineering and Information Technology, vol. 4, no. 3, pp. 129-133, 2014.

[4] T. A. Chew, A. B. Md. Isa, and M. G. Mohayidin, "The sago industry in Malaysia: present status and future prospects," in Proceedings of the 7th International Working Conference on Stored-Product Protection, pp. 1720-1728, Beijing, China, October 1998.

[5] W. Girsang, "Socio-economic factors that have influenced the decline of sago consumption in small islands: a case in rural Maluku, Indonesia," South Pacific Study, vol. 3, no. 2, pp. 99116, 2014.

[6] H. Barton, "The reversed fortunes of Sago and Rice, Oryza sativa, in the rainforests of Sarawak, Borneo," Quaternary International, vol. 249, pp. 96-104, 2012.

[7] A. A. Karim, A. Pei-Lang Tie, D. M. A. Manan, and I. S. M. Zaidul, "Starch from the Sago (Metroxylon sagu) palm treeproperties, prospects, and challenges as a new industrial source for food and other uses," Comprehensive Reviews in Food Science and Food Safety, vol. 7, no. 3, pp. 215-228, 2008.

[8] Craun Research Sdn. Bhd., Sungai Talau Research Station (STRS), PowerPoint slide, 2016.

[9] F. S. Jong, "The current state of sago palm harvesting and cultivation methods," in The Sago Palm-The Food and Environmental Challenges of the 21st Century, The Society of Sago Palm Studies, Ed., pp. 157-164, Kyoto University Press, Kyoto, Japan, 2015.

[10] W. R. Stanton, "Perspectives on, and future prospects for, the sago palm," Sago Palm, vol. 1, pp. 2-7, 1993.

[11] Borneo Post, "Help on the way for sago smallholders," November 2013, http://www.theborneopost.com/2013/11/20/help-onthe-way-for-sago-smallholders.

[12] D. M. Flores, "The versatile sago (Metroxylon sagu Rottb.) and its green potential for Mindanao," Banwa, vol. 5, no. 1, pp. 8-17, 2008.

[13] K. Ruddle and A. D. Rondinelli, Transforming Natural Resources for Human Development: A Resource Systems Framework for Development Policy, Resource Systems Theory and Methodology Series no. 1, United Nations University Press, Tokyo. Japan, 1983. 


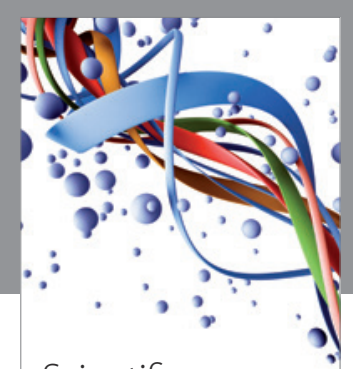

Scientifica
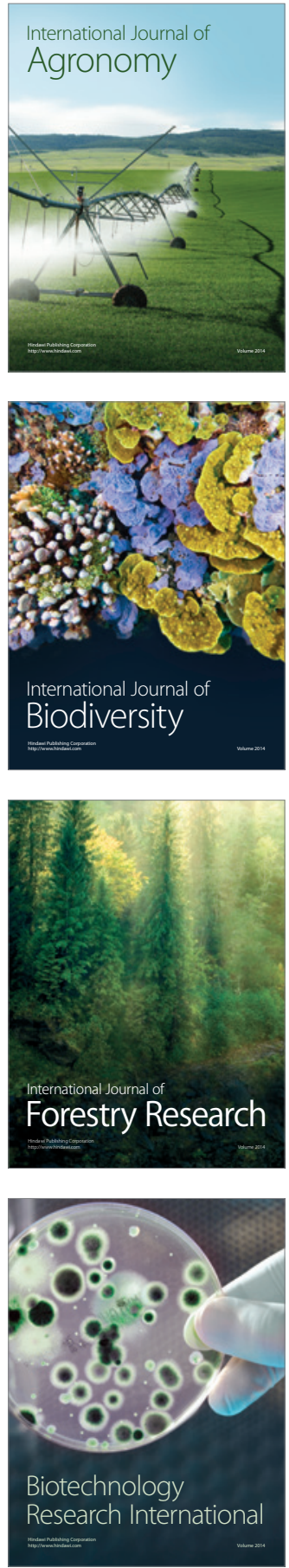
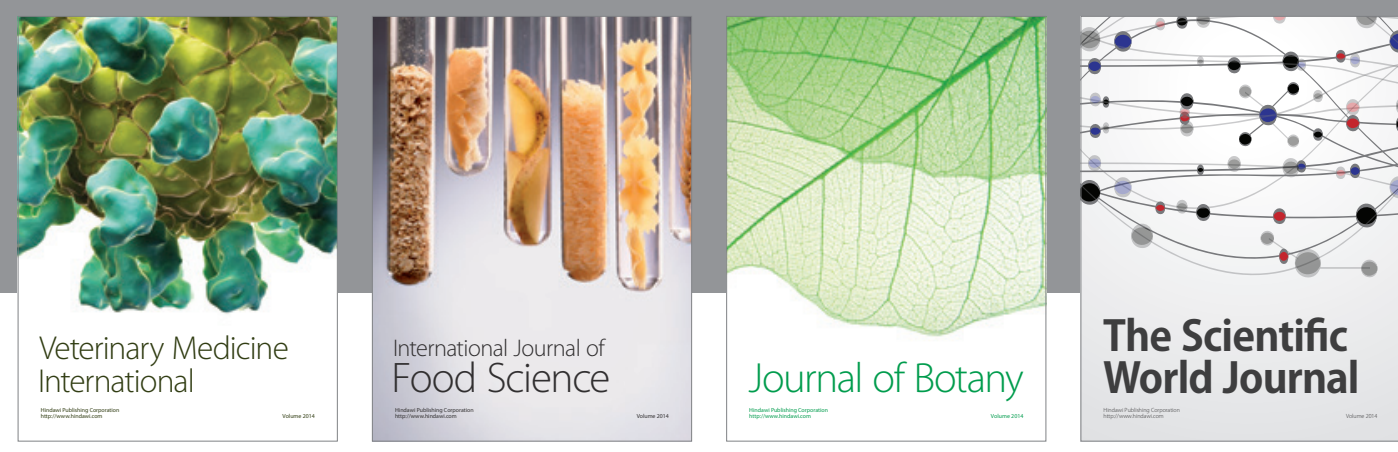

The Scientific

\section{World Journal}

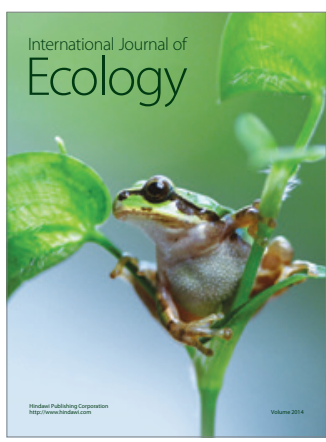

\section{Hindawi}

Submit your manuscripts at

http://www.hindawi.com
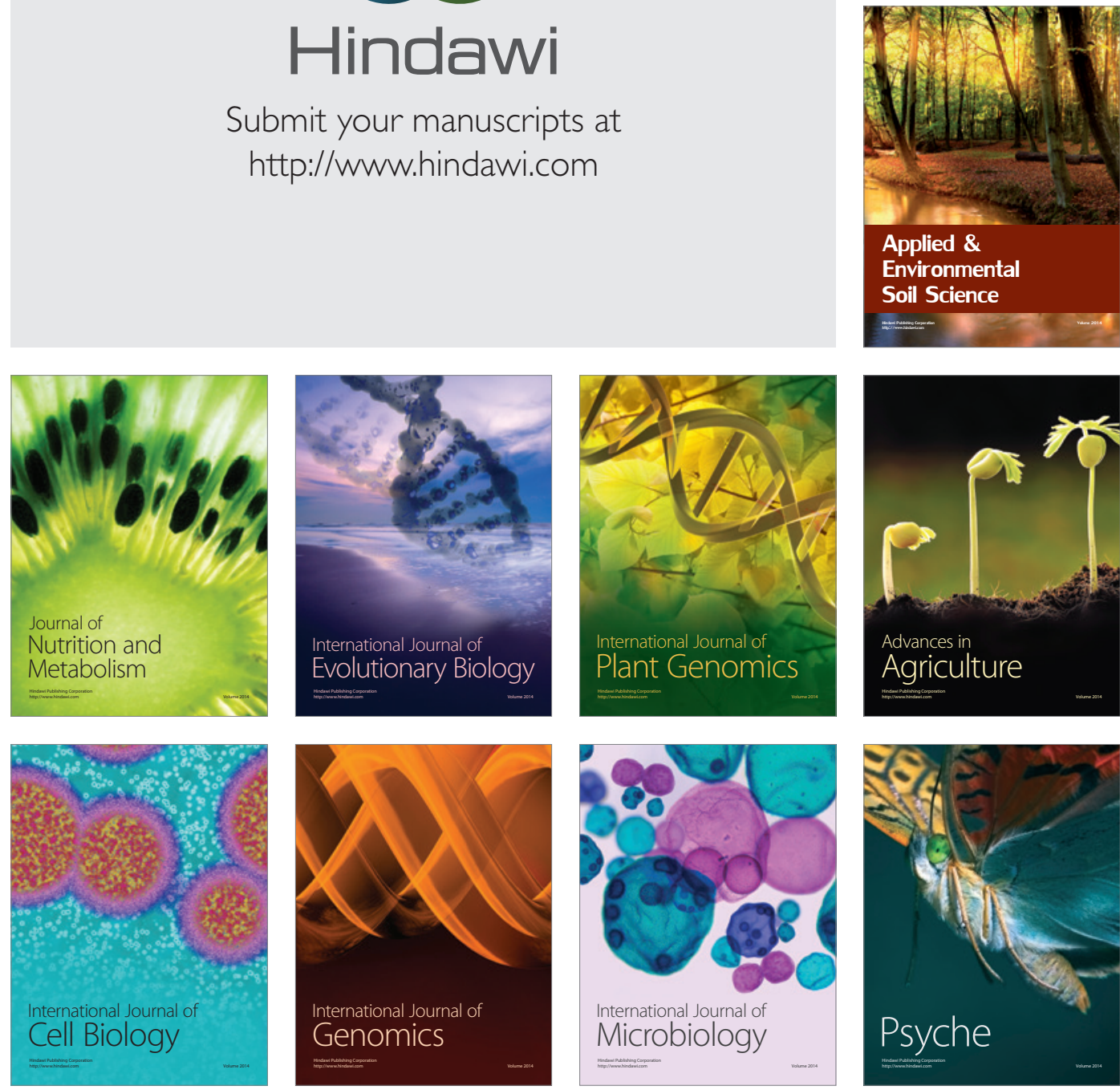
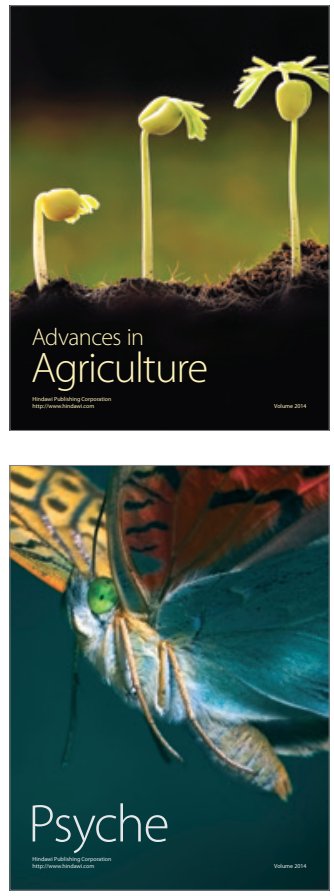